\title{
Employee turnover intention among Millennials: The role of psychological well-being and experienced workplace incivility
}

\author{
Reny Yuniasanti ${ }^{1}$, Nurul Ain Hidayah $\mathrm{Abas}^{2}$, Hazalizah Hamzah ${ }^{3}$ \\ 1,2,3 Department of Psychology and Counseling, Faculty of Human Development, Universiti Pendidikan \\ Sultan Idris, Malaysia \\ ${ }^{1}$ Faculty of Psychology, Universitas Mercu Buana Yogyakarta, Indonesia \\ ${ }^{1}$ reny.yuniasanti@mercubuana-yogya.ac.id, ${ }^{2}$ nurulain@ fpm.upsi.edu.my, ${ }^{3}$ hazalizah@fpm.upsi.edu.my
}

\section{ARTICLE INFO}

Article history

Received 4 March 2019

Revised 25 July 2019

Accepted 25 July 2019

Keywords

experienced workplace incivility psychological well-being turnover intention

\begin{abstract}
High turnover intention is a problem in the workforce today. The purpose of this study is to determine the relationship between experienced workplace incivility and psychological well-being on turnover intention. The subjects of this study were 46 millennial employees who had worked for at least three months. Data were collected with turnover intention scale, experienced workplace incivility scale, and psychological well-being scale. Partial Least Square PLS-SEM analysis was used to analyze the data. Findings indicate that experienced workplace incivility is positively related to turnover intention, while psychological well-being is negatively related to employee turnover intention. The results show that workplace incivility affects employee turnover intention higher than psychological well-being for millennial employees. Connections and communality are characteristics of millennial employees; therefore, they consider that the environment is essential. It is essential for employers to develop a work condition that minimalizes experienced workplace incivility and improves the psychological well-being of their employees to reduce turnover intention among millennial employees.
\end{abstract}

\section{Introduction}

In 2015 more than $33 \%$ of the population in Indonesia is part of the millennial generation. This number is predicted will be around 35\% in 2020, more or less 154 million people (Ali $\&$ Purwandi, 2016). The categorization of millennials or Y generations were first stated by Howe \& Strauss (2000) in a study that divided a generation cohort based on their year of birth. These categorizations are Baby Boomers (born in 1946-1964), Generation X (born in 1965-1980), Millennials or Y Generation (born in 1981-2000), and Generation Z (born in 2001-present). Luntungan, Hubeis, Sunarti, \& Maulana (2014) in their research, described millennial employees in Indonesia as individuals born in 1984-1995 who already have access to information technology. Faisal (2017) on his study in Indonesia, found the term a phi generation as a millennial generation in Indonesia, and they have five characteristics. The first characteristic is communal. They cannot live alone and like to interact and support each other. The second characteristic is simplicity in their life purpose. They only have a straight forward life plan. The millennial generation in Indonesia has a naive personality as a third characteristic. They describe themselves as kind, friendly but moody persons. The 
fourth characteristic is attention into values, they like quotes of wisdom and virtue in their daily life. The last characteristic is focused on family, happiness in their family as a priority in life.

The large population of the millennial generation is an important phenomenon that must be considered. Kultalahti \& Viitala (2014) study about millennial motivation through empirical data that collected via Facebook using method of empathy-based stories found that millennial employees are going to be more motivated if they are in a dynamic and flexible job, have a good relationship with their colleagues and supervisor. In Indonesia, some study of millennial employee behavior already explored by Saragih, Widodo, \& Prasetyo (2016). This study found that benefit, promotion opportunity, salary, the job itself, work location job flexibility, and relationship with colleagues affected organizational commitment among millennial employees. Alkhatiri (2017), based on data from the Michael Page Indonesia Employee Intentions Report, stated that $72 \%$ of respondents in Indonesia in 2015 had an interest in changing jobs in the next 12 months. Raharjo (2015) found that millennial employees had a higher turnover intention to leave work compared to Generation $\mathrm{X}$. This made the turnover intention a problem that many companies still experience today, especially those with lots of millennial employees.

Based on a study conducted by the Hay Group and Center for Economics \& Business Research carried out to 700 million employees in 19 different countries, the number of resigning employee worldwide reached 192 million in 2018. Indonesia experiences the sharpest turnover percentage in 2014, which was $27 \%$, equivalent to Russia and India in different years, and the highest compared to developed countries such as the United States, Australia, Canada, Germany, Britain, and the Netherlands. Lie \& Andreani (2017) stated that $65.8 \%$ of Indonesian millennial employees choose to leave their company after working for 12 months.

Turnover intention has a high impact on a company's performance (Setyanto \& Hermawan, 2018). If the employee's turnover rate is high, it may disrupt and reduce the company's performance. Moreover, the higher employee turnover intention, the higher the costs that the company will have to suffer, both for recruiting and for providing training for new employees.

The phenomenon of turnover intention at millennial generation becomes a problem that needs a solution. Actual turnover can be predicted by the turnover intention of the employee (Van der Heijden, Peeters, Le Blanc, \& Van Breukelen, 2018). Turnover intention is the intention to quit work or withdrawal behavior associated with alienation in work (Bothma \& Roodt, 2013). Turnover intention is a conscious willfulness to seek for other alternatives in other organizations (Bothma \& Roodt, 2013; Setyanto \& Hermawan, 2018). Theory of planned behavior explained intention behavior that consists of three components, namely perceived control, attitudes toward the behavior, and subjective norms (Sussman \& Gifford, 2018). Previous research on turnover intention in Indonesia found that paternalistic leadership is related to employee's turnover intention through satisfaction (Nurcahyanto, Rofiaty, \& Rahayu, 2018). Study on millennial generation turnover intention in Indonesia found turnover intention is influenced by job satisfaction and work overload, mediated with job satisfaction and work-related stress (Pradana \& Salehudin, 2016; Purba \& Ananta, 2018).

On their article, Jo \& Ellingson (2019) reviewed research article from 1917 until 2017. They found that from a relational lens, social relationship plays a central role in the employee's decision to stay or leave. They conclude that the presence of emotional support between coworkers will reduce turnover, but instrumental support will increases turnover (Jo \& Ellingson, 2019). This statement shows that attention and empathy from coworkers 
are significant for employees than give stuff or gift. Schaubroeck, Peng, \& Hannah (2016) found when an employee perceives low respect from co-workers, the employee will feel less accepted in the group, and this will trigger the intention to leave from the organization. Research from Ellingson, Tews, and Dachner (2016) on 397 workers employed in lowwage/low-skill service job found that social bonding between coworkers will reduce turnover intention among adult employees.

Previous research showed that organizational turnover intention might increase as employees have experienced workplace incivility (Cortina, Kabat-Farr, Leskinen, Huerta, \& Magley, 2013; Rahim \& Cosby, 2016; Rubino \& Reed, 2010). Cortina, Kabat-Farr, Magley, \& Nelson (2017) defined incivility as abusive behavior, demeaning, isolating from the surrounding environment, which violates the rules to respect at work but seemingly mediocre. According to Cortina, Magley, Williams, \& Langhout (2001), persecution such as bullying, gossiping, and speaking harshly is the lowest levels of experienced incivility at the workplace. Rahim \& Cosby (2016) found that employees would have a high level of saturation, low performance, and a high turnover intention when they got a high level of workplace incivility in the workplace. This study is supported by the results of the study by Smidt, DeBeer, Lizelle, \& Leiter (2016) that workplace incivility may have a direct impact on turnover intention. Faheem \& Mahmud (2015) with their study on 200 nurses found turnover intention among nurse were caused by workplace incivility.

Psychological well-being determined by reward, good relationships with colleagues and opportunities to feel a sense of achievement at work is another group of factors that is very important in keeping employees from moving to another company. These factors also increase motivation, morale, and employee's loyalty towards the company (Robertson \& Cooper, 2011). Desmarais \& Savoie (2012) stated that psychological well-being at work is a person's positive experience during work that related to perception about their interpersonal relation, their development, fit competence, the recognition that they felt, and their desire to be involved in the workplace. Study in Indonesia showed that employee turnover intention was significantly caused by psychological well-being (Amin \& Akbar, 2013). Considering limited research on turnover intention of the millennial employees, this research intended to explore the relationship between experienced workplace incivility and psychological wellbeing with turnover intention among millennials.

\section{Method}

\section{Research Participants}

Participants of this study were recruited using a purposive sampling method from employees that takes study at a private university in Yogyakarta. The selection criteria were employees who were born between1984 to 1995 (Luntungan et al., 2014), have access to information technology and had worked for at least three months in Yogyakarta, Indonesia. Respondents of this study consisted of 46 employees; the majority of them were male $(63.05 \%)$ and worked permanently $(65.22 \%)$ (see Table 1). Length of work period ranged from 3 months to 10 years with education level, mostly high school/ vocational high school $(84.78 \%)$. 
Table 1

Demographic Data

\begin{tabular}{lcc}
\hline Demographic & Frequency & Percentage \\
\hline Gender & & \\
Male & 29 & $63.05 \%$ \\
Female & 17 & $36.95 \%$ \\
Education & & \\
$\quad$ Senior High School & 39 & $84.78 \%$ \\
Diploma III & 3 & $6.52 \%$ \\
Bachelor Program & 4 & $8.70 \%$ \\
Type of employee & & \\
Permanent & 30 & $34.22 \%$ \\
Temporary & 16 & \\
Age & & \\
$23-27$ & 40 & $13.00 \%$ \\
$28-32$ & 6 & \\
\hline
\end{tabular}

\section{Measurement}

Three scales consisting of turnover intention scale, psychological well-being scale, and experience workplace incivility scale were used. The scales were adapted through five stages (Beaton, Bombardier, Guillemin, \& Ferraz, 2000). The first stage is a forward translation from English to Bahasa that was held by two independent translators, followed by a synthesis process that combines and integrate translation results. The third stage is back translation by two independent native translators. The fourth stage is an expert committee review involving six experts that evaluate the scales in 4 areas (semantic equivalence, conceptual equivalence, experiential equivalence, and idiomatic equivalence). The experts are academician with experience and competency on those four areas. The fifth stage is pilot-test to measure the validity and reliability of the scales.

Turnover intention (TI). The turnover intention was measured using a scale developed by Netemeyer and Brashear et al. (Hur, Kim, \& Park, 2015). Responses range in 5 range scale, from 1 (strongly disagree) to 5 (strongly agree). Each response's possible score range is 3 to 15 . A higher score on the scale shows a higher level of turnover intention. Adapted turnover intention scale has good reliability $(\alpha=.833)$ and discrimination index (.681-.895).

Psychological well-being (PWB). An index of psychological well-being in a work context is assessed using Psychological well-being scale by Desmarais \& Savoie (2012) with five dimensions: (1) interpersonal match at work; (2) developing at work, or the feeling that someone's work is significant; (3) feeling of competence; (4) recognition felt at work, or feeling valued personally in one's workplace; (5) desire for involvement in the workplace. The adapted scale has high reliability $(\alpha=.950)$ and discrimination index for 25 items ranged from $.440-.853$. Items rated on a seven-point Likert scale that is $1=$ strongly disagree to $7=$ strongly agree.

Experience Workplace Incivility (EWI). Experience workplace incivility was measured using seven items of Workplace Incivility Scale (Cortina et al., 2013). In WIS, respondents described how often they experience each incivility behavior from their colleagues and supervisors at work. They answered on a 5 -point scale $(1=$ never, $2=$ one or two times, 3 $=$ sometimes, $4=$ often to $5=$ many times). The WIS has reliability $\alpha=.861$ and discrimination index ranged from .519 to .836 . 


\section{Data Analysis}

PLS-SEM technique was used to test the hypothesis, due to small sample research and turnover intention variable is not normally distributed (Ramayah, Cheach, Chuach, Ting, \& Memon, 2018). Moreover, PLS was chosen for this study due to its ability to perform better when the objective is a prediction, and the phenomenon is relatively new or changing (Chin, Marcolin, \& Newsted, 2003). Non-parametric bootstrapping with 500 replications was applied to obtain the standard error of the estimates (Abas, Otto, \& Ramayah, 2015).

\section{Results}

Hypothesis testing was conducted to determine the relationship among experience workplace incivility, psychological well-being, and turnover intention. In order to test the significance level, $t$ statistics for all paths were generated using SmartPLS 3.0 bootstrapping function. The measurement results of all paths are shown in Figure 1 and Table 2.

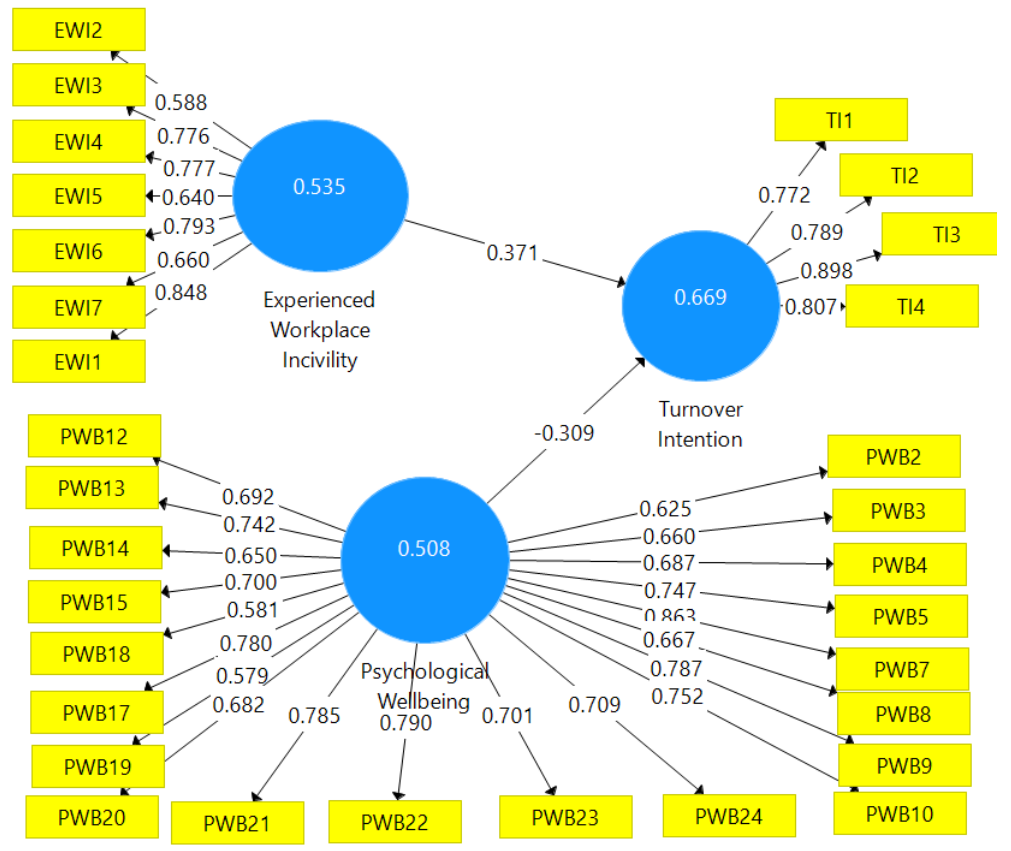

Figure 1. Result of the PLS Analysis

Figure 1 shows outer loadings, convergent validity, and the relationship of the PLS analysis. Hair, Hult, Ringle, \& Sarstedt (2017) explained that convergent validity at Smart PLS is shown with Average Variance Extracted (AVE) which is meant as a degree to which latent construct explains the variance of its indicators with minimum AVE > .5. AVE for experienced workplace incivility is .535 , psychological well-being is .508 , and turnover intention is .669. The results indicated indicators variance reflected the latent construct.

Table 2

Path Coefficients and Hypothesis Testing

\begin{tabular}{lcccccc}
\hline Hypothesis & Relationship & Beta & SE & $t$-value & $P$ Values & Decision \\
\hline H1 & EWI $\rightarrow$ TI & .371 & .132 & 3.012 & .003 & Supported \\
H2 & PWB $\rightarrow$ TI & -.309 & .172 & 1.832 & .036 & Supported
\end{tabular}


Based on the assessment of the path coefficient, as shown in Table 2, all relationships have $t$-value $\geq 1.645$ and is significant at .05 level of significance. A positive number on the $t$ values indicates experienced workplace incivility is positively related to turnover intention $(\beta=.371, \mathrm{p}<.01)$. The result means that the lower the experienced workplace incivility, the lower the turnover intention will be, and vice versa. On the contrary, there is a negative relationship between psychological well-being and turn over intention $(\beta=-.309, \mathrm{p}<.01)$. Thus, it is possible to assume that the higher psychological well-being, the lower turnover intention will be, and vice versa.

This research evaluates the model's predictive accuracy through the coefficient of determination score $\left(\mathrm{R}^{2}\right)$. Coefficient of determination this research model is $\mathrm{R}^{2}=.289$. According to Cohen (Ramayah et al., 2018), this coefficient of determination is categorized as substantial, but according to Hair et al. (2017) as weak.

Cohen (Ramayah et al., 2018) stated the $\mathrm{f}^{2}$ indicates whether the endogenous construct is relatively influenced by the constructed predictors. It measures how strong the endogenous construct determinant is contributed by exogenous constructs. Effect size to $\mathrm{R}^{2}\left(\mathrm{f}^{2}\right)$ in this mode show for experience workplace incivility is $\mathrm{f}^{2}=.182$ and for variable psychological well-being is $\mathrm{f}^{2}=.127$. According Cohen (Ramayah et al., 2018), $\mathrm{f}^{2}$ values $=$ .182 is categorised as medium effect size, while $\mathrm{f}^{2}$ values $=.127$ is categorised as small effect size. This research assesses the predictive relevance $\left(\mathrm{Q}^{2}\right)$ of the path model using blindfolding procedures after measuring the coefficient of determination score $\left(\mathrm{R}^{2}\right)$ and the effect size $\left(\mathrm{f}^{2}\right)$. According to Ramayah et al. (2018), blindfolding procedures is available in PLS software packages.

In addition, this study will also evaluate the contribution of exogenous constructs to endogenous latent variables $\mathrm{Q}^{2}$ seen from the effect size $\left(\mathrm{q}^{2}\right)$ value. Table 3 presents the level of the determinant score $\left(R^{2}\right)$, the effect size $\left(f^{2}\right)$, predictive relevance $\left(Q^{2}\right)$, and the $\mathrm{q}^{2}$ effect size of the path model. With blindfolding procedures, the predictive relevance $\left(\mathrm{Q}^{2}\right)$ of the path model of this research has values $\mathrm{Q}^{2}=.142$ of the path model. Exogenous construct has predictive relevance for endogenous constructs if the value is greater than 0 (Hair et al., 2017). The effect size of experience workplace incivility is $\mathrm{q}^{2}=.088$, it means experience workplace incivility has a little predictive relevance respectively for turnover intention variable. Psychological well-being has $\mathrm{q}^{2}=.074$, which means psychological well-being has a little predictive relevance respectively for turnover intention variable. Hair et al (2017) categorized effect size of $\mathrm{q}^{2}=.35$ is substantial, $\mathrm{q}^{2}=.15$ is moderate, $\mathrm{q}^{2}=$ .02 is weak.

Table 3

The Level of Determinant Score $\left(R^{2}\right)$, The Effect Size $\left(f^{2}\right)$, Predictive Relevance $\left(Q^{2}\right)$, and The $q^{2}$ Effect Size

\begin{tabular}{ccccc}
\hline Hypothesis & $\mathrm{R}^{2}$ & $\mathrm{f}^{2}$ & $\mathrm{Q}^{2}$ & $\mathrm{q}^{2}$ \\
\hline $\mathrm{H} 1$ & .289 & .182 & .142 & .088 \\
$\mathrm{H} 2$ & & .127 & & .074 \\
\hline
\end{tabular}

\section{Discussion}

This research reported that experience workplace incivility and psychological well-being have a significant relationship with turnover intention. The relation between workplace incivility and psychological well-being to turnover intention is categorized as substantial (Cohen, 1988). According to Cohen (1988), the meaning of substantial has a large effect, 
which means that employee will have a high turnover intention if they get high workplace incivility and have low psychological well-being simultaneously.

The turnover intention of an employee is influenced by experience workplace incivility and psychological wellbeing (28.9\%). When employee experience abusive behavior, demeaning, isolating from the surrounding environment which violates the rules to respect at work and have a low positive experience during work in the same time, they will have the intention to quit their job and company. Amin \& Akbar (2013) in their research on hotel employees found that psychological well-being negatively correlates significantly with turnover intention. This means, when an employee feels good at work and feels that their work is meaningful and has a purpose, the employee will have a low desire to quit from the company (Amin \& Akbar, 2013). Referring to Cohen's categorization of effect size (Cohen, 1988), experience workplace incivility to turnover intention has a common effect while psychological well-being has a small effect on turnover intention. Based on this, it is possible to conclude that workplace incivility affects employee turnover intention higher than psychological well-being. Liu et al. (2017) concluded that when employees receive incivility from their superior, their psychological safety will below and make them has the intention to quit. Employees that get support from their supervisor will have a low turnover intention (Fazio, Gong, Sims, \& Yurova, 2017).

In the context of millennial, one of their characteristics is a connection (Ali \& Purwandi, 2016). According to Ali \& Purwandi (2017), they are connected because the millennial generation enjoys socializing both online and offline. The communal character can also be observed on millennial employees in Indonesia. They cannot live alone, like to interact and have a relationship with other people in their community (Faisal, 2017). These characters emphasize the importance of having a good relationship with the environment. Therefore, employees who experience workplace incivility will have the intention to quit their jobs (Cortina et al., 2013; Faheem \& Mahmud, 2015; Rahim \& Cosby, 2016). Research by Leiter, Price, \& Laschinger (2010) found that nurses with X generation get more incivility from co-workers, supervisory and team than baby boomer generation, indicating different characteristics between each generation may affecting the possibility of an employee to get workplace incivility. Abubakar, Yazdian, \& Behravesh (2018) explained that the effect of active incivility at negative emotion higher at the millennial generation and baby boomer generation than $\mathrm{X}$ generation. Experience workplace incivility has a positive relationship with turnover intention among millennial employees. The lower the experience workplace incivility, the lower the turnover intention is going to be. Result of this study emphasizes finding theories from Smidt et al. (2016) that turnover intention has a direct relationship with workplace incivility among banking industry employees. It ascertains theoretical support for the study by Rahim \& Cosby (2016) that employees have a high-level turnover intention because they have frequently experienced workplace incivility. The results of this study corroborated previous research incivility. Walsh et al. (2012) stated that employees who reported a climate of civility and respect in their organization have a lower intention to quit. Dewi \& Wulanyani (2017) stated if the employee feels the climate in the shelter organization conducive and pleasant to work well, the employee is going to feel more comfortable and that will reduce turnover intention. In contrast, Sintiong \& Morshidi (2015) found that discomfort in the workplace is positively related to employee turnover intention, especially among trade union members, who came from support groups. Experience of workplace mistreatment can influence employees to seriously consider leaving the organization (Day, Kelloway, \& Hurrel, 2014).

Targets or victim of incivility in the workplace from supervisor or co-worker will feel the increase of negative emotions such as anger, sadness, and fear (Porath \& Pearson, 
2012). Victims of workplace incivility are more often experiencing greater fear and sadness and will be more likely to have higher absenteeism and the intention to quit. Their findings suggest that the social context, including uncivilized experiences of victims, may have a profound impact on sadness and ultimately cause them to leave work.

Psychological well-being is negatively correlated with the turnover intention of millennial employees. This finding reinforces Scanlan \& Still (2013) study that welfare in the workplace has a contribution to the turnover intention of the employees. Psychological wellbeing and turnover intention have a negative relationship that means the lower the PWB, the higher the turnover intention is going to be. The result of this study extended theories that assert negative association between psychological well-being and quitting intention from job and organization on millennial employees (Mcinerney, Korpershoek, Wang, \& Morin, 2018). Dickson-Swift, Fox, Marshall, Welch, \& Willis (2014) found some of the key factors in creating a work environment that brings out welfare for employee namely, personal relationships with respectful each other's, flexible work, excellent support and communication from management. When employees feel positive on their well-being, they focus on satisfying basic human needs in the workplace, clarifying desired work outcomes and increasing opportunity for individual fulfillment and growth. Therefore they do not want to quit from the organization (Amin \& Akbar, 2013).

The implication of this study is that an organization may create a civil environment and enhance the welfare of employee to minimize turnover intention. The organization can create a culture of respect where people feel safe to speak up about incivility, for example, though CREW (Civility, Respect, and Engagement at Work) process (Leiter, 2013). CREW is a series of structured gatherings among people who work together on a design to enhance participants' sensitivity to the quality of their working relationship (Leiter, 2013). With this intervention, employees will find compatibilities with their co-worker at work, allowing them to develop their competencies, to show their performance, to give rewards that will them feel valuable, and have the intention for participating in the organization. There are several limitations in this study that should be considered. First, all sample in this study came from one city. Hodgins, MacCurtain, \& Mannix-McNamara (2014) stated that when the sample is homogenous, the result cannot be generalized to other cultural contexts, in this study that is in different cities in Indonesia. Moon, Weick, \& Uskul (2017) found different responses from participants with different cultural backgrounds when faced with workplace incivility. Korean participants feel less discomfort when they imagined being confronted with uncivil actions from a person who has a higher ranking compared from lower ranking.

British participants feel similar levels of discomfort when facing uncivil behavior from low and high ranking individuals. In the culture that possesses power distance, uncivil behavior from high ranking person to someone with lower-ranking can be considered common. It is the common norm for power holders to mistreat their subordinates (Tyler, Huo, \& Lind, 2000). Future studies should consider this and provide more diverse samples from other cities in Indonesia. Second, the sample size of this research is small. Future research should use a larger sample size to get more precise results in the psychometric analysis and enhance the credibility of the results (Hodgins et al., 2014). Third, there is no data about the sources of incivility. For future research, it would be valuable to obtain the source of workplace incivility whether from people with higher position (supervisor), people with equal positions (co-workers) or from people with lower positions (subordinate). 


\section{Conclusion}

This study gives a substantial contribution to the theory about antecedents of turnover intention, especially on the millennial employees. Among millennial employees, connection is essential, therefore workplace incivility and psychological well-being affect turnover intention. The experience of workplace incivility is positively related to turnover intention among millenial employee, which means that when millennial employees frequently experience workplace incivility, they will have a high intention to leave their company. Also, the psychological well-being of millennial employees is negatively related to their turnover intention, when they feel unhappy at work, they will intend to quit.

\section{References}

Abas, N. A. H., Otto, K., \& Ramayah, T. (2015). The relationship between depressive symptoms and job satisfaction in a collectivistic culture: The moderating role of cultural embededdedness. Jurnal Psikologi Malaysia, 29(1), 1-20.

Abubakar, A. M., Yazdian, T. F., \& Behravesh, E. (2018). A riposte to ostracism and tolerance to workplace incivility: A generational perspective. Personnel Review, 47(2), 441-457. https://doi.org/10.1108/PR-07-2016-0153

Ali, H., \& Purwandi, L. (2016). Indonesia 2020: The urban middle-class millennials. Retrieved from https://www.bps.go.id/statictable/2014/09/05/974/penduduk-berumur15-tahun-ke-atas-menurut-golongan-umur-dan-jenis-kegiatan-selama-seminggu-yanglalu-1986-1996.html

Ali, H., \& Purwandi, L. (2017). Millenial Nusantara: Pahami karakternya, rebut simpatinya (Millenial nusantara: Understanding the character, win the symphaty). Jakarta: PT. Gramedia Pustaka Utama.

Alkhatiri, F. (2017). Intervensi komitmen organisasional terhadap keputusan keluarnya pegawai dari organisasi non-profit (Organisational commitment intervention to the decision to leave among employees of non profit organisation). Journal of Business Studies, 2(2), 66-79.

Amin, Z., \& Akbar, K. P. (2013). Analysis of psychological well-being and turnover intentions of hotel employees: An empirical study. International Journal of Innovation and Applied Studies, 3(3), 662-671.

Beaton, D. E., Bombardier, C., Guillemin, F., \& Ferraz, M. B. (2000). Guidelines for the process of cross-cultural adaptation of self-report measures. Spine, 25(24), 31863191. https://doi.org/10.1097/00007632-200012150-00014

Bothma, C. F. C., \& Roodt, G. (2013). The validation of the turnover intention scale. SA Journal of Human Resource Management, 11(1), 1-12. https://doi.org/10.4102/sajhrm.v11i1.507

Chin, W. W., Marcolin, B. L., \& Newsted, P. R. (2003). A partial least squares latent variable modeling approach for measuring interaction effects: Results from a Monte Carlo simulation study and an ele. Information Systems Reserach, 14(June 2003), 189-217. https://doi.org/10.1287/isre.14.2.189.16018

Cohen, J. (1988). Statistical power analysis for the behavioral sciences second edition. New York: Lawrence Erlbaum Associates.

Cortina, L. M., Kabat-Farr, D., Leskinen, E. A., Huerta, M., \& Magley, V. J. (2013). Selective incivility as modern discrimination in organizations: Evidence and impact. Journal of Management, 39(6), 1579-1605. https://doi.org/10.1177/0149206311418835 
Cortina, L. M., Kabat-Farr, D., Magley, V. J., \& Nelson, K. (2017). Researching rudeness: The past, present, and future of the science of incivility. Journal of Occupational Health Psychology, 22(3), 299-313. https://doi.org/10.1037/ocp0000089

Cortina, L. M., Magley, V. J., Williams, J. H., \& Langhout, R. D. (2001). Incivility in the workplace: Incident and impact. Journal of Occupational Health Psychology, 6(1), 64-80. https://doi.org/10/1037/1076-8998.6.1.64

Day, A., Kelloway, E. K., \& Hurrel, J. J. J. (2014). Workplace well-being: How to build psychologically healthy workplaces. West Sussex, USA: John Wiley \& Sons, Ltd.

Desmarais, V. D., \& Savoie, A. (2012). What is psychological well-being, really? A grassroots approach from the organizational sciences. Journal of Happiness Studies, 13(4), 659-684. https://doi.org/10.1007/s10902-011-9285-3

Dewi, N. A. T. M., \& Wulanyani, N. M. S. (2017). Pengaruh kepuasan kerja dan konflik kerja terhadap intensi turnover pada karyawan bank di Denpasar (The effect of job satisfaction on turnover intention among bank employees in Denpasar). Jurnal Psikologi Udayana, 4(2), 399-412.

Dickson-Swift, V., Fox, C., Marshall, K., Welch, N., \& Willis, J. (2014). What really improves employee health and wellbeing. International Journal of Workplace Health Management, 7(3), 138-155. https://doi.org/10.1108/IJWHM-10-2012-0026

Faheem, M. A., \& Mahmud, N. (2015). Workplace incivility in predicting turnover intentions and job performance: Study on nurses of public sector hospitals of Pakistan. Research Journal of Applied Sciences, Engineering and Technology, 10(8), 863-870. https://doi.org/10.19026/rjaset.10.2441

Faisal, M. (2017). Generasi Phi: Memahami milenial pengubah Indonesia (Phi generation: Understanding millennial modifiers in Indonesia). (S. Maradona \& U. Rusydan, Eds.) (1st ed.). Jakarta: Republika Penerbit.

Fazio, J., Gong, B., Sims, R., \& Yurova, Y. (2017). The role of affective commitment in the relationship between social support and turnover intention. Management Decision, 55(3), 512-525. https://doi.org/10.1108/MD-05-2016-0338

Hair, J. F., Hult, G. T. M., Ringle, C. M., Sarstedt, M., \& Thiele, K. O. (2017). Mirror, mirror on the wall: A comparative evaluation of composite-based structural equation modeling methods. https://doi.org/10.1007/s11747-017-0517-x

Hair, J. J. F., Hult, G. T. M., Ringle, C., \& Sarstedt, M. (2017). A primer on partial least squares structural equation modeling (PLS-SEM) (2nd ed.). Los Angeles: Sage publications Inc.

Hodgins, M., MacCurtain, S., \& Mannix-McNamara, P. (2014). Workplace bullying and incivility: A systematic review of interventions. International Journal of Workplace Health Management, 7(1), 54-72. https://doi.org/10.1108/IJWHM-08-2013-0030

Howe, N., \& Strauss, W. (2000). Millennials rising: The next great generation. USA: Vintage Books.

Hur, W.-M., Kim, B.-S., \& Park, S.-J. (2015). The relationship between coworker incivility, emotional exhaustion, and organizational outcomes: The mediating role of emotional exhaustion. Human Factors and Ergonomics in Manufacturing, 25(6), 701-712. https://doi.org/10.1002/hfm

Jo, J., \& Ellingson, J. E. (2019). Social relationships and turnover: A multidisciplinary review and integration. Group and Organization Management, 44(2), 247-287. https://doi.org/10.1177/1059601119834407

Kultalahti, S., \& Viitala, R. L. (2014). Sufficient challenges and a weekend ahead Generation $\mathrm{Y}$ describing motivation at work. Journal of Organizational Change Management, 27(4), 569-582. https://doi.org/10.1108/JOCM-05-2014-0101 
Leiter, M. P. (2013). Analyzing and theorizing the dynamics of the workplace incivility crisis (Vol. 8). London: Springer. https://doi.org/10.1007/978-94-007-5571-0

Leiter, M. P., Price, S. L., \& Laschinger, H. K. S. (2010). Generational differences in distress, attitudes and incivility among nurses. Journal of Nursing Management, 18(8), 970-980. https://doi.org/10.1111/j.1365-2834.2010.01168.x

Lie, V. L., \& Andreani, F. (2017). Analisis gap antara harapan dan persepsi karyawan tentang keadilan organisasi di PT Kali Jaya Putra (Gap analysis between employee's expectation and perception of organisational justice in PT Kali Jaya Putra). Agora, 5(1), 1-6.

Liu, C., Chen, Y., Yu, S., Hu, S., Huang, J., \& Ding, C. (2017). Supervisor incivility, psychology safety and employee turnover intention: Does supervisor-subordinate guanxi matter?, 8(9), 79-90. https://doi.org/10.30845/ijbss

Luntungan, I., Hubeis, A. V. S., Sunarti, E., \& Maulana, A. (2014). Strategi pengelolaan generasi Y di industri perbankan (Management strategies of generation Y in banking industry). Jurnal Manajemen Teknologi, 13(2), 219-240. https://doi.org/10.12695/jmt.2014.13.2.7

Mcinerney, D. M., Korpershoek, H., Wang, H., \& Morin, A. J. S. (2018). Teachers' occupational attributes and their psychological wellbeing, job satisfaction, occupational self-concept and quitting intentions. Teaching and Teacher Education, 71, 145-158. https://doi.org/10.1016/j.tate.2017.12.020

Moon, C., Weick, M., \& Uskul, A. K. (2017). Cultural variation in individuals' responses to incivility by perpetrators of different rank: The mediating role of descriptive and injunctive norms. European Journal of Social Psychology, 48(4), 472-489. https://doi.org/10.1002/ejsp.2344

Nurcahyanto, D., Rofiaty, R., \& Rahayu, M. (2018). Paternalistic leadership on gen-Y employees' turnover intentions with motivation and satisfaction as a mediator. Jurnal Aplikasi Manajemen, 16(4), 622-629. https://doi.org/10.21776/ub.jam.2018.016.04.08

Porath, C. L., \& Pearson, C. M. (2012). Emotional and behavioral responses to workplace incivility and the impact of hierarchical status. Journal of Applied Social Psychology, 42(SUPPL. 1). https://doi.org/10.1111/j.1559-1816.2012.01020.x

Pradana, A., \& Salehudin, I. (2016). Work overload and turnover intention of junior auditors in greater Jakarta, Indonesia. The South East Asian Journal of Management, 9(2), 108-124. https://doi.org/10.21002/seam.v9i2.4950

Purba, S. D., \& Ananta, A. N. D. (2018). The effects of work passion, work engagement and job satisfaction on turnover intention of the millennial generation. Jurnal Manajemen Dan Pemasaran Jasa, 263. https://doi.org/10.25105/jmpj.v11i2.2954

Raharjo, E. K. C. R. (2015). Perbedaan intensi turnover berdasarkan kategori generasi karyawan (Differences in turnover intention based on employee generation categories). Universitas Gadjah Mada. Retrieved from http://etd.repository.ugm.ac.id/index.php?act=view\&buku_id=92784\&mod=penelitia $\mathrm{n} \_$detail\&sub=PenelitianDetail\&typ=html

Rahim, A., \& Cosby, D. M. (2016). A model of workplace incivility, job burnout, turnover intentions, and job performance. Journal of Management Development, 35(10), 12551265. https://doi.org/10.1108/JMD-09-2015-0138

Ramayah, T., Cheach, J., Chuach, F., Ting, H., \& Memon, M. A. (2018). Partial least squares structural equation modeling (PLS-SEM) using smartPLS 3.0. Kuala Lumpur: Pearson Malaysia.

Robertson, I., \& Cooper, C. (2011). Well-being: Productivity and happiness at work (1st 
ed.). New York: Palgrave Macmillan.

Rubino, K. M., \& Reed, W. D. (2010). Testing a moderated mediational model of workgroup incivility: The roles of organizational trust and group regard. Journal of Applied Social Psychology, 40(April 2008), 3148-3168. https://doi.org/10.1111/j.1559-1816.2010.00695.x

Saragih, E. H., Widodo, A., \& Prasetyo, B. (2016). Big city millenial workers in Indonesia and factors affecting their commitment to the organisation. Pertanika Journal of Social Sciences and Humanities, 24(May), 47-58. https://doi.org/10.13140/RG.2.1.3222.2961

Scanlan, J. N., \& Still, M. (2013). Job satisfaction, burnout and turnover intention in occupational therapists working in mental health. Australian Occupational Therapy Journal, 60(5), 310-318. https://doi.org/10.1111/1440-1630.12067

Schaubroeck, J. M., Peng, A. C., \& Hannah, S. T. (2016). The role of peer respect in linking abusive supervision to follower outcomes: Dual moderation of group potency. Journal of Applied Psychology, 101(2), 267-278. https://doi.org/10.1037/ap10000050

Setyanto, S. H., \& Hermawan, P. (2018). Analisa pengaruh stres kerja terhadap turnover intention karyawan Hotel X Surabaya (Analysis of the effect of job stress to turnover intention among employees of Hotel X Surabaya). Jurnal Hospitality Dan Manajemen Jasa, 6(2015), 245-254.

Sintiong, M., \& Morshidi, A. H. (2015). Workplace incivility and turnover intention among bank employees in Sabah, (November), 13. https://doi.org/10.13140/RG.2.1.3378.4408

Smidt, O., DeBeer, L. T., Lizelle, B., \& Leiter, M. P. (2016). The validation of a workplace incivility scale within the South African banking industry. SA Journal of Industrial Psychology, 42(1), 1-12. https://doi.org/10.4102/sajip.v42i1.1316

Sussman, R., \& Gifford, R. (2018). Causality in the theory of planned behavior. Personality and Social Psychology Bulletin, 45(6), 920-933. https://doi.org/10.1177/0146167218801363

Tyler, T. R., Huo, Y. J., \& Lind, E. A. (2000). The psychology of conflict resolution across cultures. Psychology, Public Policy, and Law Journal, 6(4), 1138-1163. https://doi.org/10.1037//1076-8971.6.4.1138

Van der Heijden, B. I. J. M., Peeters, M. C. W., Le Blanc, P. M., \& Van Breukelen, J. W. M. (2018). Job characteristics and experience as predictors of occupational turnover intention and occupational turnover in the European nursing sector. Journal of Vocational Behavior, 108(June), 108-120. https://doi.org/10.1016/j.jvb.2018.06.008

Walsh, B. M., Magley, V. J., Reeves, D. W., Davies-Schrils, K. A., Marmet, M. D., \& Gallus, J. A. (2012). Assessing workgroup norms for civility: The development of the civility norms questionnaire-brief. Journal of Business and Psychology, 27(4), 407420. https://doi.org/10.1007/s10869-011-9251-4 